\title{
Toxicological Studies in Albino Rats Maintained on Fish Smoked with Firewood and Waste Tyre Materials
}

Ujowundu $\mathrm{CO}^{1 *}$, Igwe $\mathrm{KO}^{1}$, Agha $\mathrm{NC}^{1}$ and Okechukwu RI ${ }^{2}$

${ }^{1}$ Department of Biochemistry, Federal University Technology Owerri, Nigeria

${ }^{2}$ Department of Biotechnology, Federal University Technology Owerri, Nigeria

\begin{abstract}
Tyres are a mixture of vulcanized or cross-linked polymers, carbon black, dispersing oil, sulphur, synthetic fibres, pigments, processing chemicals and steel/fiberglass. Burning of tyre materials produces smoke and toxic air pollutants, including benzene, dioxins, furans, heavy metals and polycyclic aromatic hydrocarbons (PAHs). We investigated the effects of the accumulation of these toxicants on fish smoked with waste tyre materials as fuel source on liver function and oxidative stress parameters in Albino Wistar rats. In this toxicological study, some of the rats were exposed to diets formulated with the smoked fish and some were allowed diets formulated with smoked fish and/or Solanum lycopersicum and Allium cepa. At the end of the study period, the liver function parameters (total protein, albumin, AST, ALP, ALT, bilirubin and cholesterol) indicated negative hepatic changes with adverse fluctuations in oxidative stress parameters (GPx, catalase, SOD, GSH and MDA). Incorporation of S. Iycopersicum and A. cepa in the diets ameliorated these adverse biochemical changes in rats exposed to fish smoked with these toxic materials.
\end{abstract}

Keywords: Heavy metals; PAHs; Dioxins; Smoked fish; Waste tyre; Toxicants; Antioxidants; Solanum lycopersicum; Allium cepa

\section{Introduction}

Chemicals produced during food processing, storage, transport and from the environment are sources of exposure to food toxins and contaminants. PAHs, dioxins and heavy metals are important compounds associated with ecological and health problems.

Polycyclic aromatic hydrocarbons (PAHs), is a ubiquitous compound of hydrogen and carbon with two or more fused aromatic rings. PAHs are chemically persistent organic compounds generated from the incomplete pyrolysis of organic compounds [1,2]. They are commonly produced during domestic food preparation processes (such as grilling, roasting, smoking, etc.) that exposes the food to direct contact with the fire, smoke and high temperature $[3,4]$. The toxic effect of PAHs is generated by its metabolites which bind to protein and DNA, causing biochemical disruption and cell damage in animals and cancer in humans [5]. There are three principal pathways for metabolism of PAHs: the pathway via bay region dihydrodiol epoxide by cytochrome $\mathrm{P}_{450}$ enzymes (CYPs), the pathway via radical cation by one-electron oxidation, and the ortho-quinone pathway by dihydrodiol dehydrogenase (DD) [6].

Dioxins are certain group of compounds containing benzene rings and varying numbers of chlorine atoms at different positions of these rings. Dioxins [polychlorinated dibenzo-p-dioxin (PCDDs)] and furans [polychlorinated dibenzofurans (PCDFs)] are produced by tyre incineration. Hydrocarbons (the bulk of the tyre and firewood) and oxygen (from the air) are readily available when tyre is incinerated. Most thermal process leads to the formation of dioxins, because they are characterized by the presence of organic matter, chlorine, high temperature $\left(200-900^{\circ} \mathrm{C}\right)$ and low concentration of oxygen [7]. One important source of chlorine in tyres is its content of halogenated butyl rubber liners. The addition of chlorine or bromine (the latter used more widely for truck tyres) to the butyl rubber gives liners the airpermeability required to maintain proper tyre inflation. Furthermore the presence of metals in tyres serve as catalyst for the synthesis of dioxin, providing a surface on which dioxins can readily form during and after the combustion process. Dioxins are highly toxic and cause serious health problems such as infertility, learning disabilities, endometriosis, sexual reproductive disorders, birth defects, damage to the immune system and cancer $[7,8]$.

Roasting and/or smoking foods with firewood produce PAHs in the foods [4]. Therefore, using firewood and waste tyres materials as source of fuel in food preparation may increase the level of PAHs, dioxins and heavy metals. Roasted foods have advantages such as palatability, aesthetic quality and the speed of preparation. However, the adverse health consequences of unregulated consumption of these foods are important. The knowledge of sources of exposure, possible amounts and their damaging effects are pertinent to helping us avoid them or check our intake of such foods. Environmental risk assessment of foods, commonly consumed is important for healthy living. Since roasting/smoking foods is a very common method of food processing in many Nigerian homes $[4,9]$, their potential hazards ought to be brought to the knowledge of consumers.

\section{Materials and Methods}

\section{Materials}

Healthy male albino rats of Wistar strain (Rattus norvegicus) that weighed between $50 \mathrm{~g}$ and $90 \mathrm{~g}$ were purchased from the Zoological department of the University of Nigeria, Nsukka. They were kept in cages where they were fed with rat pellets. The rat feed used was manufactured by Vital Poultry Growers Pellets, a product of Grand feed Nigeria Ltd. The fish used for the experiment was purchased from Obinze market in Owerri, Imo state.

*Corresponding author: Ujowundu, Department of Biochemistry, Federa University Technology Owerri, Nigeria, Tel: +234 8036683491; E-mail: ujowundu@ yahoo.com

Received December 02, 2014; Accepted December 26, 2014; Published December 31, 2014

Citation: Ujowundu CO, Igwe KO, Agha NC, Okechukwu RI (2014) Toxicological Studies in Albino Rats Maintained on Fish Smoked With Firewood and Waste Tyre Materials. J Environ Anal Toxicol 4: 258. doi: 10.4172/2161-0525.1000258

Copyright: @ 2014 Ujowundu CO, et al. This is an open-access article distributed under the terms of the Creative Commons Attribution License, which permits unrestricted use, distribution, and reproduction in any medium, provided the original author and source are credited. 


\section{Feed preparation}

The onions and tomatoes were purchased from Relief market, Owerri; they were cut into small pieces and dried at room temperature for four (4) weeks. Finally, they were oven dried at $40^{\circ} \mathrm{C}$ for two days, ground and stored in labelled, air tight containers.

Fresh fish samples were purchased from a local market and were roasted on a locally set up kiln, The fish samples were roasted by exposing them to the heat, smoke and flame generated by firewood and waste tyre material as energy sources for over four hours at high temperature.. They were ground and stored properly in well labelled, air tight containers and stored in a dark cupboard.

\section{Formulation of diet}

The feed was formulated as shown in the Table 1. An analytical balance was used to accurately weigh the different samples to prepare the diets and the formulated diets were stored in well labelled, air tight containers.

\section{Experimental design}

The experimental protocol of this study was reviewed and approved by the ethics committee of the Department of Biochemistry, Federal University of Technology, Owerri, Nigeria. The rats were housed in clean metal cages, maintained at room temperature in an animal house with constant photoperiod of $12 \mathrm{~h}$ light/dark cycle for two weeks for acclimatization. They were allowed rats pellet and water ad libitum. The rats were divided into six groups, six in each. The rats in each group were allowed the formulated diets as described in Table 1 for four weeks. The rats in group 1 (fed with $100 \%$ feed) served as control. Water was provided ad libitum. The rats were sacrificed after 24 hours fast. Blood and liver samples were taken for liver function, oxidative stress parameters and cholesterol determinations.

\section{Biochemical analyses}

Biuret method was used for the qualitative determination of the total protein in serum [10]. Bilirubin was determined by the colorimetric method based on that described by Jendrassik and Grof [11]. ALT and AST were measured by monitoring the concentration of pyruvate hydrazone and oxaloacetate, formed respectively, with 2, 4- dinitrophenyl hydrazine [12]. Alkaline phosphatase activity was determined by the Englehardt et al. [13] method. Serum albumin was determined based on its qualitative binding to the indicator $3,3^{\prime}$, $5,5^{\prime}$ - tetrabromo- $\mathrm{m}$ cresol sulphonepthalein [14]. Serum cholesterol concentration by the methods described by Allain et al. [15] and Melattini et al. [16]. Liver homogenate was used for the assessment of oxidative stress parameters. Catalase (CAT) activity was determined as described by Aebi [17], superoxide dismutase (SOD) as described by Xin et al. [18]. Glutathione peroxidase (GPx) activity by the method of Paglia and Valentine [19]. King and Wootton [20] method was used to determine reduced glutathione (GSH) and malondialdehyde (MDA)

\begin{tabular}{|l|l|}
\hline Group & Feed Composition \\
\hline Group 1 & $100 \%$ feed \\
\hline Group 2 & $60 \%$ feed $+40 \%$ wood fish \\
\hline Group 3 & $60 \%$ feed $+40 \%$ tyre fish \\
\hline Group 4 & $50 \%$ feed $+40 \%$ tyre fish $+10 \%$ tomato \\
\hline Group 5 & $50 \%$ feed $+40 \%$ tyre fish $+10 \%$ onion \\
\hline Group 6 & $50 \%$ feed $+40 \%$ tyre fish $+5 \%$ tomato $+5 \%$ onions \\
\hline
\end{tabular}

Table 1: Percentage (\%) composition of the processed onion, tomato and fish samples concentration (a marker of lipid peroxidation) was determined by the method described by Wallin et al. [21].

\section{Statistical analysis}

The results were analysed using Duncan's Multiple Range test. All data were expressed as mean \pm standard deviation. Differences between groups were considered at $95 \%$ confidence limit and probability level of $0.05(\mathrm{p}<0.05)$ was taken as significant.

\section{Results and Discussion}

Increases in transaminases are markers of hepatocellular damage and leakage of enzymes through damaged cell membranes [22]. It indicates that the hepatic intracellular enzymes have leaked into circulation [23]. The significant increase observed when the groups fed the smoked fish diets were compared with the control indicates hepatic damage resulting from the toxicants present in the smoked fish diets (Table 3). This assertion is in line with the work of Ujowundu et al. [24] which observed that PAHs and heavy metals in diet, reacts readily with hepatocellular components, inducing toxicity via epoxide formation. Yoon et al. [25] observed an increase in liver mass during and a rise in ALT activity in the serum of murine model, administered $100 \mu \mathrm{g} /$ $\mathrm{kg}$ b.w. of 2, 3, 7, 8-tetrachlorodibenzo-p-dioxin (TCDD) a standard compound of PCDDs.

Alkaline phosphatase is ubiquitous with regard to tissue distribution, but its concentrations are high in the liver, bone, intestine and placenta. A healthy liver contains ALP and other substances which drain continually through the bile duct. Lobular damage may obstruct the flow of bile, causing accumulation of ALP which is regurgitated back into the plasma [26,27]. The significant increase in ALP activity observed in rats exposed to tyre smoked fish without concomitant feeding with either onion or tomato or both when compared with other groups (Table 3), indicates hepatic damage. This corroborates the work done by Eteng et al. [28].

Impaired hepatic function affects albumin and plasma proteins, leading to disturbances in their plasma concentration [29]. The significant decrease in albumin and total protein concentration observed in the groups exposed to smoked fish without concomitant feeding with either onion or tomato or both when compared with control (Table 2 ), is consistent with the trend observed in liver diseases and damage involving impaired liver function [29,30]. This study observed a nonsignificant increase in bilirubin concentration in rat groups exposed to fish smoked with firewood and tyre compared to the control (Table 2). Also, a significant increase in cholesterol concentration was recorded in rats fed fish smoked with tyre without supplement (Table 2). These indicate a gradual compromise in liver function [31]. Bilirubin, a breakdown product of red blood cell haemoglobin is removed from the blood through the bile by a healthy and functional liver. However, diseases of the liver are often accompanied by increased levels of bilirubin in the system. Also, the increase in cholesterol buttresses a gradual dysfunction of the liver. Furthermore, the finding of Ivens et al. [32] indicated that, accumulation of dioxins in the liver could modify the metabolism of cholesterol and hormones. And since these compounds are involved in plasma proteins synthesis, hepatocytes accumulation of dioxins may change the peripheral blood status and influence the biochemical response to an inflammatory reaction. However, the nonsignificant change in cholesterol in the supplemented groups could be attributed to the antioxidant (flavonoids) and hypocholestrolemic (saponins) properties of the supplements, which may have given some chemoprotection $[33,34]$. 


\begin{tabular}{|c|c|c|c|c|}
\hline Groups & T. Protein (g/l) & Albumin(g/ I) & Bilirubin $(\mu \mathrm{mol} / \mathrm{I})$ & Cholesterol(mmol/l) \\
\hline Control & $74.23 \pm 1.72^{\mathrm{a}}$ & $38.50 \pm 0.70^{a}$ & $8.40 \pm 2.74^{\mathrm{a}}$ & $1.76 \pm 0.39^{b}$ \\
\hline Firewood FD & $59.70 \pm 7.54^{b}$ & $31.80 \pm 1.83^{b}$ & $9.17 \pm 0.81^{\mathrm{a}}$ & $1.68 \pm 0.03^{b}$ \\
\hline Tyre FD & $59.93 \pm 5.12^{\mathrm{b}}$ & $31.30 \pm 3.94^{b}$ & $9.63 \pm 2.36^{\mathrm{a}}$ & $3.41 \pm 0.27^{\mathrm{a}}$ \\
\hline Tyre FD+tomato & $67.80 \pm 6.63^{\text {ba }}$ & $33.33 \pm 0.31^{b}$ & $9.23 \pm 1.76^{a}$ & $1.86 \pm 0.12^{b}$ \\
\hline Tyre FD+onion & $64.23 \pm 6.60^{\text {ba }}$ & $32.93 \pm 2.48^{b}$ & $9.43 \pm 1.05^{\mathrm{a}}$ & $1.59 \pm 0.19^{b}$ \\
\hline Tyre FD+tomato+onion & $73.27 \pm 5.68^{a}$ & $32.67 \pm 3.04^{b}$ & $9.43 \pm 1.45^{a}$ & $1.99 \pm 0.09^{b}$ \\
\hline
\end{tabular}

Values are expressed as mean \pm standard deviation. Values with the different superscript per column are significantly different $(p<0.05)$.

Table 2: Liver functions parameter and total cholesterol of rats maintained on diets formulated with smoked fish and treated with tomato and onion.

\begin{tabular}{|c|c|c|c|}
\hline GROUP & ALT (u/l) & AST (u/l) & ALP (u/l) \\
\hline Control & $31.33 \pm 3.06^{\mathrm{a}}$ & $67.33 \pm 1.54^{\mathrm{a}}$ & $7.47 \pm 0.38^{\mathrm{a}}$ \\
\hline Firewood FD & $64.33 \pm 2.08^{\mathrm{b}}$ & $78.00 \pm 5.29^{\mathrm{a}}$ & $12.07 \pm 1.10^{\mathrm{b}}$ \\
\hline Tyre FD & $64.33 \pm 10.26^{\mathrm{b}}$ & $152.0 \pm 24.58^{\mathrm{b}}$ & $18.77 \pm 2.76^{\mathrm{c}}$ \\
\hline Tyre FD+tomato & $46.67 \pm 2.08^{\mathrm{c}}$ & $73.33 \pm 5.03^{\mathrm{a}}$ & $10.50 \pm 1.25^{\mathrm{a}, \mathrm{b}}$ \\
\hline Tyre FD+onion & $58.33 \pm 4.73^{\mathrm{b}}$ & $105.33 \pm 11.02^{\mathrm{c}}$ & $11.67 \pm 3.00^{\mathrm{b}}$ \\
\hline Tyre FD+tomato+onion & $58.33 \pm 4.73^{\mathrm{b}}$ & $117.33 \pm 17.01^{\mathrm{c}}$ & \\
\hline
\end{tabular}

Values are expressed as mean \pm standard deviation. Values with the different superscript per column are significantly different $(p<0.05)$.

Table 3: Liver enzyme activities in rats maintained on diets formulated with smoked fish and treated with tomato and onion.

\begin{tabular}{|c|c|c|c|c|c|}
\hline GROUP & (U/g tissue) & (U/g tissue) & (U/g tissue) & (mg/g tissue) & (\% TBARS) \\
\hline Control & $0.39 \pm 0.23^{b}$ & $41.52 \pm 5.38^{a, b}$ & $3.10 \pm 0.63^{b}$ & $0.83 \pm 0.06^{a}$ & $1.74 \pm 0.63^{a, b}$ \\
\hline Firewood FD & $0.046 \pm 0.01^{\mathrm{a}}$ & $32.85 \pm 2.49^{b}$ & $0.62 \pm 0.16^{\mathrm{a}}$ & $0.67 \pm 0.15^{\mathrm{b}, \mathrm{c}}$ & $2.75 \pm 0.27^{b, c}$ \\
\hline Tyre FD & $0.020 \pm 0.004^{a}$ & $37.23 \pm 4.17^{\mathrm{a}, \mathrm{b}}$ & $0.43 \pm 0.15^{\mathrm{a}}$ & $0.33 \pm 0.06^{c}$ & $3.48 \pm 1.11^{\circ}$ \\
\hline Tyre FD+tomato & $0.096 \pm 0.02^{\mathrm{a}}$ & $37.12 \pm 4.02^{\mathrm{a}, \mathrm{b}}$ & $0.90 \pm 0.77^{a}$ & $0.63 \pm 0.15^{\mathrm{b}, \mathrm{c}}$ & $1.28 \pm 0.11^{\mathrm{a}}$ \\
\hline Tyre FD+onion & $0.073 \pm 0.037^{a}$ & $38.00 \pm 4.60^{\mathrm{a}, \mathrm{b}}$ & $2.08 \pm 0.25^{b}$ & $0.63 \pm 0.15^{\mathrm{b}, \mathrm{c}}$ & $1.99 \pm 0.40^{\mathrm{a}, \mathrm{b}}$ \\
\hline Tyre FD+tomato+onion & $0.076 \pm 0.021^{a}$ & $42.86 \pm 5.46^{a}$ & $2.70 \pm 1.04^{b}$ & $0.57 \pm 0.15^{\mathrm{b}}$ & $2.07 \pm 0.23^{a, b}$ \\
\hline
\end{tabular}

Values are expressed as mean \pm standard deviation. Values with the different superscript per column are significantly different $(p<0.05)$.

Table 4: Oxidative stress parameters in rats maintained on diets formulated with smoked fish and treated with tomato and onion.

The chemoprotective significance of onion and tomato were further observed from the activities of some antioxidative enzymes (Table 4). Under normal physiological conditions, the antioxidative defence system allows the elimination of excessive reactive oxygen species. A non-significant increase in GPx, SOD and CAT activities was noted in the groups fed onion/tomato supplemented diet when compared to the tyre group. Increased GPx activity is a mechanism among antioxidant enzymes in response to increased oxidative stress [35]. SOD and CAT combines to protect cells from superoxides and hydrogen peroxide [36], their reduced activities observed in this study (Table 4) indicates possible exhaustion due to their radical scavenging roles at sites of liver injury [24].

Other compounds used in monitoring oxidative stress are glutathione (GSH) and malondialdehyde (MDA). GSH is the most abundant non-protein thiol in cells that participates in several biochemical processes. GSH occurs in red blood cells mostly in reduced form, affecting the free radicals scavenging functions [37,38]. The use of GSH in protective roles against oxidants may have resulted in its significantly reduced concentration in rats fed with fish smoked with tyre materials (Table 4) [39]. The metabolites of hydrolytic degradation of dioxins (a major product of tyre combustion) by monooxygenase are conjugated with glucuronic acid or the glutathione molecule (GSH) and released from organisms with urea or bile [40]. The supportive roles of the antioxidant constituents of the supplements were observed in the non-significant reduction of GSH in the supplemented groups. The significantly increased $(\mathrm{P}<0.05)$ MDA concentration recorded in the groups fed diets formulated with fish smoked with firewood and tyre materials (Table 4) indicates increased lipid peroxidation initiated by free radicals generated by their toxic contents (PAHs, dioxins and heavy metals) which are deleterious to the cells and organs [41]. However, groups fed the diets supplemented with onion and tomato, maintained low MDA concentration within that of the unexposed. Increased MDA is an indicator of lipid peroxidation and thus oxidative stress $[42,43]$.

\section{Conclusion}

This study has shown that onions (Allium cepa) and tomato (Solanium lycopersicum) have both hepatoprotective and antioxidative potentials. From the results obtained, there were obvious attempts by the plants content to maintain the animal's system. Allium cepa and Solanium lycopersicum are good sources of phytochemicals and may have contributed [24]. Awareness should be made to the public about the dangers of constantly consuming smoked, grilled and barbequed foods, and if they must be taken, adequate onions (Allium cepa) and tomatoes (Solanium lycopersicum) should be incorporated into their diets.

\section{References}

1. Cross AJ, Sinha R (2004) Meat related mutagens/carcinogens in the etiology or colorectal cancer. Environ Molecular Mutagenesis 44: 44-55.

2. Rey Salguerio L, Garcia Falcon MS, Nez Carballo EM, Samal Gandara J (2008) Effects of toasting procedures on the level of PAHs in toasted bread. Food chemist 108: 607-615.

3. Suchanová M, Jana Haj L, Tomaniová M, Kocourek V, Babika L (2008) Polycyclic aromatic hydrocarbons in smoked cheese. J Sci Food Agric 88: 1307-1317.

4. Ujowundu CO, Inekweazu KL, Alisi CS, Ujowundu FN, Igwe CU (2014) Procarcinogens: Polycyclic Aromatic Hydrocarbons and Heavy Metal Content in Some Locally Processed Foods in South Eastern Nigeria. British J Applied Sci Technol 4: 249-260.

5. Armstrong B, Hutchinson E, Unwin J, Flecher T (2004) Lung cancer risk afte exposure to Polycyclic Aromatic Hydrocarbons: A review and meta-analysis. Environ Health perspective 112: 970-978. 
Citation: Ujowundu CO, Igwe KO, Agha NC, Okechukwu RI (2014) Toxicological Studies in Albino Rats Maintained on Fish Smoked With Firewood and Waste Tyre Materials. J Environ Anal Toxicol 4: 258. doi: 10.4172/2161-0525.1000258

Page 4 of 4

6. Xue W, Warshawsky D (2005) Metabolic activation of polycyclic and heterocyclic aromatic hydrocarbons and DNA damage: A review. Toxico Applied Pharmacol. 206(1): 73-93.

7. Całkosiński I, Rosińczuk-Tonderys J, Bazan J, Dobrzyński M, BronowickaSzydełko A, et al. (2014) Influence of dioxin intoxication on the human system and possibilities of limiting its negative effects on the environment and living organisms. Ann Agric Environ Med 21: 518-524.

8. Kogevinas M (2011) Epidemiological approaches in the investigation of environmental causes of cancer: the case of dioxins and water disinfection byproducts. Environ Health. 10:S3.

9. Ujowundu CO, Ogbede JU, llechukwu MA, Ekwonwa AJ, Agha NC et al. (2014) Quantitative assessment of polycyclic aromatic hydrocarbons and heavy metals in fish roasted with waste tyres and polyethylene materials. Biochem Anal Biochem. Biochem-14-507.

10. Burtis CA, Ashwood ER, Bruns DE, (2005) Tietz Textbook of Clinical Chemistry and Molecular Diagnostics, $4^{\text {th }}$ ed. W.B Sauders Co. Philadelphia.

11. Jendrassik L, Grof P (1938) Vereinfachte, photometrische methoden zur Bestimmung des blutbilirubins. Biochem Z 297:81-89

12. Reitman S, Frankel S (1957) A colorimetric method for the determination of serum glutamic pyruvic transaminases. Amer J Pathol 28: 56-63

13. Englehardt A (1970) Measurement of alkaline phosphatase. Aerztl Labor 16:42.

14. Doumas BT, Watson WA, Biggs HG (1971) Albumin standards and measurement of serum albumin with bromocresol green. Clin Chim Acta 31:8796.

15. Allain CC, Poon LS, Chan CSG, Richmond W, Fu PC (1974) Enzymatic determination of total serum cholesterol. Clin Chem 20: 470-475.

16. Melanttni F, Prencipe L, BradellI F, Giannini G, Tarli P (1978) The 4aminobenzoate/ 4- aminophenazone chromogenic system used in the enzymatic determination of cholesterol. Clin Chem 24: 2161-2165

17. Aebi HE (1984) Catalase in vitro. In Methods in enzymatic analysis. Bergmeyer HU (edt) Academic press New York 3:273

18. Xin Z, Waterman DF, Henken RM, Harmon RJ, (1991) Effects of Copper Status on neutrophil function, superoxide dismutase and copper distribution in stress. J Diary Sci 74: 3078-3085.

19. Paglia DE, Valentine WN (1967) Studies on the quantitative and qualitative characterization of erythrocyte glutathione peroxidase. J Lab Clin Med 70: 158169.

20. King KJ, Wootton IDP (1959) Microanalysis in medical Biochemistry 14.

21. Wallin B, Rosengren B, Shertzer HG, Cameyo G, (1993) Lipoprotein oxidation and measurement of TBARS formation in a single microlitrepeate; its use for evaluation of antioxidants. Annual Rev Med 208: 10-15.

22. Kale SN, Polyhronopoulous JM, Aldrich PJ, Mendosa JH, Suh JH (2001) Prospective study of hepatic, renal and heamatological surveillance in hazardous material firefighters. Occup Environ Med 58: 87-94.

23. Han N, Ntoo HK, Aung H (2012) Diabetes Res 1: 34-36.

24. Ujowundu CO, Okoye HN, Nwaoguikpe RN, Belonwu DC, Igwe KO, et al (2014) Hepatoprotective Effects of Crude Extracts of Tomato and Onion in Rats Exposed to Locally Processed Beef. J of Biochem Res Inter Rev 4: 193-203.

25. Yoon CY, Park M, Kim BH, Park JY, Park MS, et al. (2006) Gene expression profile by 2,3,7,8-tetrachlorodibenzo-p-dioxin in the liver of wild-type (AhR+/+) and aryl hydrocarbon receptor-deficient (AhR-/-) mice. J Vet Med Sci 68: 663668.

26. Guyton AC, Hall JE (2000) Textbook of Medical Physiology. (10 $10^{\text {th }}$ edtn) WB Saunders 787-802.

27. Nyblom H, Berggren U, Balldin J, Olsson R (2004) High AST/ALT ratio may indicate advanced alcoholic liver diease rather than heavy drinking. Alcohol Alcohol 39 (4): 336-339.

28. Eteng MU, Ibekwe HA, Abolaji AO, Okoi Al, Onwuka FC, et al. (2009) Effect of Rauwolfia Vomitoria Afzel (Apocynaceae) Extract on Serum Amino Transferase and Alkaline Phosphatase Activities and Selected Indices of Liver and Kidney Functions. Afr J Biotechnol 8: 4604-4607.

29. Keith G, Ashwood ER, Robert R (1999) Liver Function In Burtis CA, Ashwood ER Tietz Textbook of Clinical Chemistry ( $3^{\text {rd }}$ edition). Philadelphia WB Saunders
Company. 1125-1177

30. Oluwatosin OS, Francis AA, Olabamiji AA (2007) Biochemical Parameters of Liver Function in Artisans Occupationally Exposed to "Vat Dyes". Indian J Occup Environ Med 11: 76-79.

31. Imafidan KE, Okunrobo LO (2012) Study of Biochemical Indices of LFTs on Albino Rats Supplemented With Sources of Vegetable Oils. J Basic Applied Sci 20: 105-110.

32. Ujowundu CO, Kalu FN, Okafor EO, Agha CN, Alisi CS, et al. (2010) Evaluation of the chemical composition of Dacryodes edulis (G.Don) seeds. Int J Bio Chem Sci 4: 1225-1233.

33. Ivens IA, Loser E, Rinke M, Schmidt U, Neupert M (1992) Toxicity of 2,3,7,8 tetrabromodibenzo-p-dioxin in rats after single oral administration. Toxicol 73 : 53-69.

34. Onyeike EN, Monanu MO, Okoye CN (2012) Changes in the Blood Lipid Profile of Wistar Albino Rats Fed With Rich Cholesterol Diets. Annals Bioll Res. 3 5186-5191.

35. Li G, Xin F, Sheng W (2005) Effects of Cu/ Zn Superoxide Dismutase on StrainInjury Induced Oxidative Damage to skeletal muscle in rats. Physiol Res 54 193-199.

36. Jose MM, Cristina PE, Ignacio ND (1999) Antioxidant Enzymes and Human Diseases. Clin Biochem 32: 595-603.

37. Celik I, Suzek H (2009) Effects of Subacute Exposure of Dichlorous at Sublethal dosages on erythrocytes and Tissue Antioxidant Defence Systems and Lipid Peroxidation in Rats. Ecotoxicol Environ Saf 72: 905-908.

38. Bukowska B (2013) Effects of 2, 4-D and its metabolite 2,4- dichlorophenol on Antioxidant Enzymes and Level of Glutathione in human Erythrocytes. Comp Biochem Physio Toxicol Pharmcol 135: 435-441.

39. Luay AA, Tareq YA (2014) Antioxidants and Some Biochemical Parameters in Workers Exposed to Petroleum Station Pollutants in Mosul City, Iraq. Inter Res J Environ Sci 3: 31-37.

40. Fantini AG, Yoshioka T (1993) Desferroxamine prevents lipid peroxidation and attenuates reoxygenation injury in postischemic skeletal muscle. Am J Physio 264: H1953-H1959.

41. Tijet N, Boutros PC, Moffat ID, Okey AB, Tuomisto J, et al. (2006) Ary hydrocarbon receptor regulates distinct dioxin-dependent and dioxinindependent gene batteries. Mol Pharmacol 69: 140-153.

42. Chessman KH, Slater TF (1993). An Introduction to Free Radical Biochemistry. Br Med Bull 49(3): 481- 493. 